\title{
DEBT DEFAULT DAN FINANCIAL DISTRESS SEBAGAI DETERMINAN PENERIMAAN OPINI AUDIT GOING CONCERN
}

\author{
Ferdiansyah Ritonga, Dhela Febi Setiawati Putri \\ Program Studi Akuntansi \\ STIE STAN Indonesia Mandiri, Jl. Jakarta No. 79 Bandung
}

\begin{abstract}
ABSTRAK
Tujuan dari penelitian ini adalah untuk mengetahui pengaruh debt default dan financial distress terhadap opini audit going concern pada perusahaan industri pertambangan yang terdaftar di Bursa Efek Indonesia pada periode 2014-2016. Sampel dalam penelitian ini adalah 37 perusahaan dalam kurun waktu selama 3 tahun. Teknik pengambilan sampel dengan menggunakan metode purposive sampling. Metode analisis yang digunakan adalah metode regresi logistik.

Hasil penelitian ini yaitu secara simultan, variabel debt default dan financial distress secara bersama-sama berpengaruh positif dan signifikan terhadap opini audit going concern. Dan hasil penelitian secara persial menunjukan (1) variabel debt default berpengaruh negatif tidak signifikan terhadap opini audit going concern, (2) variabel financial distress berpengaruh negatif signifikan terhadap opini audit going concern.
\end{abstract}

Kata kunci: Debt Default, Financial Distress, dan Opini Audit Going Concern.

\section{PENDAHULUAN}

Opini audit going concern dianggap sebagai asumsi untuk berinvestasi karena kreditor tidak mungkin menginvestasikan dananya pada perusahaan yang terindikasi mengalami kebangkrutan (Putri dan Merkusiwati, 2014). Opini auditor merupakan sumber informasi bagi pihak diluar perusahaan sebagai pedoman untuk pengambilan keputusan. Hanya auditor yang berkualitas yang dapat menjamin bahwa laporan (informasi) yang dihasilkan reliable (Praptitorini dan Januarti, 2011).

Werastuti (2013) berpendapat bahwa penelitian mengenai opini audit going concern di Indonesia masih menjadi objek penelitian yang penting dan menarik dilakukan karena mengingat bahwa opini audit going concern suatu badan usaha merupakan salah satu hal yang mendasari para investor dalam pengambilan keputusan investasi dan juga para keditor dalam meminjamkan dananya dengan tujuan untuk memperoleh laba dari aktifitas tersebut, selain itu opini audit going concern sering dihubungkan dengan kemampuan manajemen perusahaan untuk lebih mempertahankan kelangsungan hidup usahanya. Kelangsungan hidup suatu usaha (going concern) merupakan asumsi dasar dalam penyusunan laporan keuangan, karena itu perusahaan 
diasumsikan tidak bermaksud atau berkeingian untuk melikuidasi atau menguangi secara material skala usahanya (Standar Akuntansi Keuangan, 2002).

Banyak orang menganggap bahwa opini wajar tanpa pengecualian (clean opinion) yang diberikan oleh auditor adalah jaminan bahwa suatu perusahaan tidak akan pailit dalam waktu dekat. Akibat anggapan ini, banyak auditor kemudian dihakimi berdasarkan pailit tidaknya suatu perusahaan (Kesumojati et al., 2017). Hal ini tidak terlepas dari reputasi Kantor Akuntan Publik yang memeriksa perusahaan-perusahaan yang bersangkutan. Secara umum, bila reputasi KAP kurang baik, seperti perusahaan big four, tingkat keindependensian dari auditor mereka akan lebih percaya. Tapi apabila reputasi KAP kurang baik dimata publik, kepercayaan terhadap hasil opini audit dengan paragraf going concern pun bisa saja diragukan (Wulandari, 2014).

Dari segi positifnya, pengeluaran opini audit going concern sangat berguna bagi para pemakai laporan keuangan untuk membuat keputusan yang tepat dalam berinvestasi (Wulandari, 2014). Perlunya untuk mengetahui sehat tidaknya kondisi keuangan perusahaan yang merupakan asumsi dasar bagi investor dalam melakukan investasinya, terutama yang menyangkut dengan kelangsungan hidup perusahaan tersebut (Siregar dan Rahman, 2012).

Pendapat going concern menjadi lebih penting dan menjadi perhatian bagi praktisi dan peneliti setelah mencuatnya kasus-kasus manipulasi laporan keuangan perusahaan yang terjadi dalam beberapa dekade terakhir ini, seperti kasus Enron dan WorldCom dengan KAP Anderson, serta di Indonesia sendiri seperti kasus PT. Kimia Farma Tbk, PT. Indosat Tbk, dan kasus sembilan KAP yang mengaudit bank-bank, dan kasus lainnya (Siregar dan Rahman, 2012). Perikatan audit yang dilakukan oleh Arthur Andersen (AA) sudah hampir 20 tahun, seharusnya AA banyak mengetahui mengenai kliennya. Kemudian Ernst dan Young dinyatakan lalai dengan mengeluarkan opini wajar tanpa pengecualian bagi Lehman sebelum terjadinya early warning dalam opini yang diberikannya tersebut agar pihak-pihak yang berkepentingan pada laporan keuangan yang telah diaudit tidak salah berinvestasi (Werastuti, 2013).

Masalah going concern merupakan hal yang cukup kompleks dan terus ada, sehingga diperlukan faktor-faktor sebagai tolak ukur yang pasti untuk menentukan status going concern pada perusahaan (Kesumojati et al., 2017). Verdiana dan Utama (2013) menyimpulkan disclosure berpengaruh positif dan signifikan pada kemungkinan 
pengungkapan opini audit going concern. Penelitian yang dilakukan oleh Sari dan Wahyuni (2014) menyimpulkan bahwa variabel yang mempengaruhi pemberian opini audit going concern adalah variabel kualitas audit dan solvabilitas terhadap penerimaan opini audit going concern. Penelitian lain yang dilakukan oleh Krissindiastuti dan Rasmini (2016) menunjukan bahwa variabel reputasi KAP dan opinon shopping berpengaruh positif terhadap opini audit going concern. Handayani (2015) menunjukan bahwa variabel audit tahun sebelumnya berpengaruh terhadap penerimaan opini audit going concern. Kemudian Nanda dan Siska (2015) menunjukan bahwa opinion shopping dan kondisi keuangan berpengaruh terhadap penerimaan opini audit going concern. Kesumojati et al., (2017) menyimpulkan bahwa financial distress dan debt default berpengaruh signifikan terhadap penerimaan opini audit going concern. Penelitian oleh Fauziyah (2015) menunjukan variabel yang memiliki pengaruh terhadap penerimaan opini audit going concern adalah kepemilikan institusional, leverage, kepercayaan manajerial, dan financial distress.

Penelitian kali ini mengangkat dua variabel dari beberapa variabel yang pernah diteliti sebelumnya yaitu debt default dan financial distress terhadap penerimaan opini audit going concern. Alasan mengambil variabel tersebut karena peneliti ingin mengetahui apakah variabel-variabel tersebut berpengaruh atau tidak terhadap penerimaan opini audit going concern pada perusahaan industri pertambangan yang terdaftar di Bursa Efek Indonesia pada periode yang diteliti.

Pernyataan Standar Auditing 30 (2001) dalam Rahmat (2016) indikator going concern yang banyak digunakan auditor dalam memberikan keputusan audit adalah kegagalan dalam memenuhi kewajiban hutangnya (default). Jika perusahaan dalam kondisi ini, maka kemungkinan mengalami kebangkrutan sangat besar. Ketika jumlah hutang perusahaan sudah sangat besar, maka aliran kas perusahaan akan banyak dialokasikan untuk menutupi hutangnya, sehingga akan mengganggu kelangsungan operasi perusahaan. Apabila hutang tak mampu dilunasi maka kreditor memberikan status default (Rahmat, 2016; Suharsono, 2018).

Ketika suatu perusahaan mengalami kesulitan keuangan bahkan kegagalan bisnis hingga terancam akan bangkrut maka perusahaan tersebut diyakini mengalami masalah, sehingga perusahaan tersebut diragukan dalam mempertahankan kelangsungan hidupnya, kondisi dimana perusahaan mengalami kesulitan keuangan dan terancam 
bangkrut dikenal dengan financial distress (Yuliani dan Erawati, 2017). Masalah keuangan yang dihadapi suatu perusahaan apabila dibiarkan berlarut-larut dapat mengakibatkan terjadinya kebangkrutan (Andre, 2014). Financial distress dapat mendorong pemegang saham untuk mengganti manajer perusahaan karena manajer dianggap tidak mampu mengelola perusahaan dengan baik. Hal tersebut akan mendorong manajer untuk merubah laba yang menjadi salah satu tolak ukur kinerja manjer dengan jalan mengatur tingkat konvertisme akuntansi (Novianti dan Ratnadi, 2015).

Penelitian ini dilakukan karena adanya hasil inkonsistensi dari hasil penelitian terdahulu mengenai faktor-faktor yang mempengaruhi opini audit going concern. Penelitian ini diharapkan dapat memberikan kontribusi untuk literarur mengenai hubungan debt default dan financial distress terhadap opini audit going concern.

Nirmalasari (2014) menyatakan bahwa status debt default pada perusahaan berpengaruh positif terhadap penerimaan opini audit going concern. Penelitian tersebut didukung oleh Sandi et al., (2014) yang menunjukan bahwa variabel debt default berpengaruh positif terhadap penerimaan opini audit going concern. Pernyataan tersebut diperkuat oleh penelitian yang dilakukan oleh Alamanda (2015).

Namun beberapa penelitian lain menunjukan hasil yang berbeda oleh Putri et al., (2016) yang menunjukan bahwa debt default berpengaruh negatif pada opini audit going concern. Adapun penelitian yang dilakukan oleh Ibrahim (2015) menyimpulkan bahwa variabel debt default tidak berpengaruh terhadap opini audit going concern.

Faktor lain yang dianggap memengaruhi opini audit going concern adalah financial distress. Menurut Fauziyah (2015) menunjukan bahwa financial distress berpengaruh terhadap opini audit going concern. Kesumojati et al., (2017) menyimpulkan bahwa variabel financial distress berpengaruh signifikan terhadap penerimaan opini audit going concern.

Penelitian lain menunjukan hasil yang berbeda oleh Sidqi dan Sutapa (2014) menyatakan bahwa variabel financial distress berpengaruh negatif terhadap penerimaan opini audit going concern. Pernyataan tersebut sejalan dengan penelitian yang dilakukan oleh Hasanah (2015) dan Juliana (2013) yang menunjukan bahwa financial distress berpengaruh negatif terhadap penerimaan opini audit going concern. 
Perusahaan industri pertambangan yang terdaftar di BEI periode 2014-2016 dipilih untuk menjadi populasi penelitian kali ini karena pada tahun 2015 perusahaan pertambangan sedang mengalami kerugian dan penurunan kapitalisasi pasar. 40 perusahaan pertambangan global terbesar mencatat kerugian bersih kolektif (US\$27 miliar). Ini merupakan yang pertama dalam sejarah dimana kapitalisai pasar turun sebesar 37\%. Ditahun 2015 tidak ada perusahaan pertambangan di Indonesia dengan Kapitalisasi pasar melebihi US\$4 miliar. Kapitalisasi pasar keseluruhan perusahaan pertambangan yang tercatat di Bursa Efek Indonesia turun dari Rp 255 triliun pada tanggal 31 Desember 2014 menjadi 161 triliun pada tanggal 31 Desember 2015 (http://pwc.com/, 2016). Sebanyak kurang lebih 125 perusahaan pertambangan batu bara di Kalimantan Timur tidak beroperasi. Lesunya iklim bisnis disebabkan banyak faktor. Antara lain faktor internasional, terkait lesunya perekonomian dunia, turunnya harga minyak mentah, minimnya permintaan akan komoditas batu bara yang diikuti penurunan harga (http://ekonomi.kompas.com/, 12 Agustus 2015). Sektor pertambangan merupakan salah satu pilar pembangunan ekonomi nasional Indonesia. Harga komoditas SDA yang kuat dan kembalinya minat investor atas industri pertambangan telah memacu nilai pasar perusahaan (http://kompasiana.com/, 31 Desember 2013).

\section{REVIEW LITERATUR DAN PENGEMBANGAN HIPOTESIS}

\subsection{Going Concern}

Istilah going concern atau keberlanjutan usaha merupakan asumsi akuntansi yang mengharapkan sebuah usaha dapat berlanjut terus dalam waktu yang tak terbatas, juga disebut continuity. Hal ini merupakan dasar untuk menggunakan daya historis dalam menilai perkiraan yang lebih baik dari pada nilai likuidasi, karena perusahaan dianggap akan terus-menerus ada (Islahuzzaman, 2012:164). Dengan adanya going concern maka suatu badan usaha dianggap mampu mempertahankan kegiatan usahanya dalam jangka waktu yang panjang, tidak akan dilikuidasi dalam jangka waktu pendek (Murtin dan Choirul, 2008).

Istiana (2010) mendefinisikan going concern adalah kelangsungan hidup suatu entitas yang merupakan tanggung jawab utama director untuk menentukan kelayakan dan persiapan laporan keuangan menggunakan dasar going concern dan tanggung jawab 
auditor untuk meyakini dirinya bahwa peggunaan dasar going concern oleh perusahaan adalah layak dan diungkapkan secara memadai dalam laporan keuangan.

Asumsi kelangsungan usaha (going concern) memiliki arti bahwa suatu badan usaha dianggap dapat mempertahankan keberlangsungan usahanya dalam periode waktu yang lama dan tidak akan bangkrut dalam periode yang cepat. Laporan audit yang berhubungan dengan kelangsungan usaha digunakan oleh para pemegang saham dan pengguna laporan keuangan agar terhindar dari kesalahan dalam pembuatan keputusan (Rahmat, 2016). Laporan keuangan adalah informasi akuntansi yang menggambarkan tentang posisi keuangan perusahaan serta hasil usaha perusahaan pada periode yang berakhir pada tanggal tertentu, yang terdiri atas neraca, daftar laba rugi, perubahan ekuitas, arus kas dan informasi lainnya (Islahuzzaman, 2012:242). Apabila laporan keuangan disusun dengan dasar going concern, berarti diasumsikan perusahaan akan bertahan dalam jangka panjang (Nanda dan Siska, 2015).

\subsection{Opini Audit Going Concern}

Opini audit going concern merupakan bed news bagi pemakai laporan keuangan (Tandungan dan Mertha, 2016). Rahayu (2007) dalam Suharsono (2018) menyatakan bahwa istilah going concern dapat diinterprestasikan dalam dua hal, yang pertama adalah going concern sebagai konsep dan yang kedua adalah going concern sebagai opini audit. Sebagai konsep, istilah going concern dapat diinterprestasikan sebagai kemampuan perusahaan mempertahankan kelangsungan usahanya dalam jangka panjang. Sebagai opini audit, istilah going concern menunjukan auditor memiliki kesangsian mengenai kemampuan perusahaan untuk melanjutkan usahanya dimasa mendatang.

Siregar dan Rahman (2012) mengungkapkan beberapa hal yang dapat mempengaruhi auditor dalam menerbitkan opini audit going concern adalah sebagai berikut :

1. Tren negatif, misalnya kerugian operasi yang berulang kali, kekurangan modal kerja, arus kas negatif, dan rasio keuangan penting yang jelek.

2. Petunjuk lain tentang kemungkinan kesulitan keuangan, misalnya kegagalan dalam memenuhi kewajiban utangnya untuk perjanjian serupa, penunggakan pembayaran dividen, serta penjualan sebagian besar aset. 
3. Masalah internal, misalnya pemogokan kerja, ketergantungan besar atas suksesnya suatu proyek.

4. Masalah eksternal, misalnya pengaduan gugatan pengadilan, keluarnya undangundang yang mengacam keberadaan perusahaan, kehilangan franchise (hak kelola), lisensi atau paten yang penting, bencana yang tidak diasuransikan, dan kehilangan pelanggan atau pemasok utama.

\subsection{Debt Default}

Debt default adalah kegagalan debitor (perusahaan) dalam membayar utang pokok atau bunganya pada waktu jatuh tempo (Chen dan Church, 2002; Praptitorini, 2007; Werastuti, 2013). Status debt default dilihat pada laporan keuangan perusahaan bagian laporan auditor independen pada paragraf penjelas (Susanti dan Zubaidah, 2015).

Dalam PSA 30 going concern yang banyak digunakan auditor dalam memberikan keputusan opini audit adalah kegagalan dalam memenuhi kewajiban hutangnya (default).

Hutang didefinisikan oleh FABS sebagai pengorbanan manfaat ekonomi dimasa yang akan datang yang muncul dari kewajiban khusus suatu badan usaha saat ini untuk mentransfer aktiva atau menyediakan jasa pada badan usaha lain dimasa yang akan datang sebagai akibat transaksi atau kejadian dimasa lalu (Ikhsan dan Suprasto, 2008:178). Hutang memiliki kemampuan untuk meningkatkan kapasitas pendanaan sebuah perusahaan sehingga mampu untuk memenuhi kebutuhan perusahaan tersebut (Sanusi, 2016).

\subsection{Financial Distress}

Purwati dan Yuliandhari (2014), mendefinisikan financial distress merupakan tahapan kondisi keuangan suatu perusahaan sebelum terjadinya kebangkrutan atau likuidasi. Kebangkrutan biasanya diartikan sebagai kegagalan perusahaan dalam menjalankan operasi perusahaan untuk menghasilkan laba (Aminah dan Sanjaya, 2013).

Kondisi financial distress merupakan kondisi keuangna dimana keuangan perusahaan dalam keadaan tidak sehat atau krisis. Financial distress yang cukup mengganggu kegiatan operasional perusahaan merupakan suatu kondisi yang harus segera diwaspadai dan diantisipasi (Carolina et al., 2017). 
Fachrudi (2008) dalam Caroline et al., (2017) ada beberapa definisi kesulitan keuangan menurut tipenya, antara lain sebagai berikut:

1. Economic Failure

Kegagalan ekonomi merupakan kondisi dimana pendapatan perusahaan tidak cukup untuk menutupi total biaya, termasuk cost of capital. Dalam kondisi ini perusahaan dapat melanjutkan operasinya sepanjang kreditur bersedia menerima tingkat pengembalian (rate of return) yang dibawah pasar.

\section{Business Failure}

Kegagalan bisnis merupakan keadaan dimana bisnis yang menghentikanoperasi dengan alas an mengalami kerugian. Sudah tidak dapat melanjutkan aktivitasnya.

3. Technical Insolvency

Kondisi perusahaan dapat dikatakan dalam keadaan technical insolvency jika suatu perusahaan tidak dapat memenuhi kewajiban lancarnya ketika jatuh tempo.

4. Legal Banckruptcy

Bisnis dianggap mengalami kebangkrutan secara hukum apabila perusahaan tersebut melaporkan kejadian dan tuntutan secara resmi sesuai dengan undangundang yang berlaku.

5. Insolvency in Banckruptcy

Insolvency in banckruptcy terjadi sebelum legal bankruptcy dimana suatu perusahaan memiliki nilai buku hutang melebihi nilai pasar asset saat ini. Keadaan ini dapat dianggap lebih serius jika dibandingkan dengan technical insolvency, karena pada umumnya hal tersebut merupakan tanda kegagalan ekonomi, yang jelas mengarah pada likuidasi bisnis.

\subsection{Pengembangan Hipotesis}

\subsubsection{Pengaruh Debt Default terhadap Opini Audit Going Concern}

Istiana (2010) melakukan penelitian dengan data sekunder dan didapat sebanyak 53 perusahaan manufaktur pada Bursa Efek Indonesia periode 2006-2008. Hasil penelitian membuktikan bahwa variabel debt default berpengaruh positif terhadap opini audit going concern.

Praptitorini dan Januarti (2011) melakukan penelitian pada seluruh perusahaan manufaktur yang tidak keluar (delisting) periode 1997-2002 dari Bursa Efek Indonesia, 
sampel dalam penelitian ini diperoleh dengan metode purposive sampling. Hasil akhir menunjukan bahwa variabel debt default berpengaruh signifikan terhadap opini audit going concern.

Penelitian lain dengan topik penelitian yang sejenis yang dilakukan oleh Nirmalasari (2014) menggunakan purposive sampling dan memperoleh 141 sampel perusahaan manufaktur yang listing di Bursa Efek Indonesia pada periode 2010-2012 dan regresi logistik dipilih sebagai metode analisisnya. Hasil penelitian membuktikan bahwa debt default berpengaruh positif signifikan terhadap opini audit going concern.

Penelitian lain oleh Sandi et al., (2014) pada seluruh perusahaan yang terdaftar di Bursa Efek Indonesia periode 2011-2013 dengan teknik purposive judgement sampling method. Hasil menunjukan bahwa variabel debt default berpengaruh positif terhadap opini audit going concern.

Alamanda (2015) melakukan penelitian pada 335 perusahaan manufaktur yang terdaftar di Bursa Efek Indonesia pada tahun 2009-2013 dengan teknik purposive sampling. Hasil akhir menunjukan bahwa debt default berpengaruh positif terhadap opini audit going concern.

Penelitian yang dilakukan oleh Harris dan Merianto (2015) pada 24 perusahaan manufaktur yang terdaftar di Bursa Efek Indonesia dari tahun 2008-2012, metode penelitian yang digunakan adalah purposive sampling. Hasil penelitian menunjukan bahwa variabel debt default berpengaruh signifikan terhadap opini audit going concern.

Rahmat (2016) menggunakan purposive sampling sebagai teknik pengambilan sampelnya. Populasi yang diambil adalah 33 perusahaan Real Estate and Property yang terdaftar di Bursa Efek Indonesia periode 2011-2013. Hasil penelitian tersebut membuktikan bahwa variabel debt default berpengaruh signifikan terhadap opini audit going concern.

Penelitian yang dilakukan oleh Imani et al., (2017) dengan jumlah populasi sebanyak 10 perusahaan pertambangan yang terdaftar di Bursa Efek Indonesia pada periode 2012-2015. Metode analisis data dalam penelitian ini adalah regresi logistik menggunakan purposive sampling. Penelitian ini menunjukan hasil bahwa variabel debt default berpengaruh terhadap opini audit going concern.

Penelitian lain oleh Kesumojati et al., (2017) pada perusahan yang terdaftar di Bursa Efek Indonesia dari tahun 2011-2015. Pengambilan sampel menggunakan metode 
purposive sampling dan diperoleh sampel sebanyak 32 perusahaan dari 160 observasi.. Hasil penelitian menunjukan bahwa variabel debt default berpengaruh signifikan terhadap opini audit going concern.

Suharsono (2018) melakukan penelitian tentang debt default terhadap opini audit going concern dengan sampel sebanyak 35 perusahaan industri manufaktur yang terdaftar di Bursa Efek Indonesia pada tahun 2009-2011. Hasil penelitian menunjukan bahwa variabel debt default berpengaruh positif terhadap opini audit going concern.

Status hutang perusahaan merupakan faktor pertama yang akan diperiksa oleh auditor dalam laporan keuangan untuk mengukur kesehatan keungan perusahaan. Posisi kewajiban atau hutang perusahaan jangka pendek maupun jangka panjang merupakan faktor penting bagi sudut pandang auditor dalam melaksanakan tugasnya karena posisi hutang yang tidak terbayarkan hingga melewati batas jatuh tempo dapat mencerminkan kelangsungan perusahaan.

Kegagalan dalam memenuhi kewajiban hutang dan atau bunganya merpakan indikator going cocern yang banyak dilakukan oleh auditor dalam menilai kelangsungan hidup suatu perusahaan. Jika perusahaan gagal dalam membayar atau memenuhi hutangnya secara berangsur-angsur maka bunganyapun akan semakin membesar. Dalam kondisi ini auditor akan menimbulkan keraguan atas kemampuan perusahaan untuk dapat melanjutkan usahanya dan auditor bertanggung jawab atas opini yang dikeluarkannya karena akan menyangkut pada pihak eksteral perusahaan. Kegagalan perusahaan membayar hutang dan bunganya pada saat jatuh tempo akan mempengaruhi perusahaan dalam menjalankan usahanya. Sehingga kemungkinan opini audit going concern akan dikeluarkan oleh auditor

Ketika jumlah hutang perusahaan sudah sangat besar, maka keuangan akan mengalami masalah dan aliran kas perusahaan akan lebih banyak dialokasikan untuk menutupi semua hutang perusahaan tersebut, penyebabnya akan mengganggu kelangsungan dan aktifitas operasi perusahaan. Dalam hal ini pula, minat investor akan menurun karena investor akan lebih memilih perusahaan yang siklus keuangannya normal atau sehat. 


\subsubsection{Pengaruh Financial Distress terhadap Opini Audit Going Concern}

Yuliani dan Erawati (2017) melakukan penelitian tentang pengaruh financial distress terhadap opini audit going concern pada perusahaan manufaktur yang terdaftar di Bursa Efek Indonesia periode 2010-2015 dengan metode purposive sampling sebanyak 150 sampel dan di dapat 25 perusahaan yang dijadika sampel dalam penelitian tersebut. Hasil akhir menunjukan bahwa variabel financial distress berpengaruh negatif terhadap opini audit going concern.

Hasanah (2015) melakukan penelitian yang bersifat kuantitatif pada 34 sampel perusahaan manufaktur periode 2010-2013 yang terdaftar di Bursa Efek Indonesia, selain itu data diperoleh dari data-data relevan perpustakaan Universitas Bina Nusantara, literatur-literatur, jurnal, dan situs-situs internet. Berdasarkan pengujian dengan menggunakan regresi logistik menunjukan bahwa variabel financial distress berpengaruh negatif terhadap opini audit going concern.

Sidqi dan Sutapa (2014) pada seluruh perusahaan manufaktur periode 2010-2012 yang terdaftar di Bursa Efek Indonesia dengan menggunakan metode purposive sampling. Berdasarkan pengujian dengan menggunakan regresi logistik menunjukan hasil bahwa variabel financial distress berpengaruh negatif terhadap opini audit going concern.

Penelitian lain yang dilakukan oleh Purwati dan Yuliandhari (2014) pada perusahaan manufaktur yang terdaftar di Bursa Efek Indonesia tahun 2009-2012 dan didapat sebanyak 18 perusahaan untuk dijadikan sampel penelitiannya. Hasil penelitian membuktikan bahwa financial distress tidak berpengaruh secara signifikan terhadap opini audit going concern.

Jenis data penelitian yang dilakukan oleh Juliana (2013) adalah data sekunder berupa laporan keuangan yang telah dipublikasikan oleh Bursa Efek Indonesia selama tahun 2006-2010. Setelah digunakan tekhnik purposive sampling maka didapat sebanyak 21 perusahaan yang menjadi penelitian tersebut. Hasil penelitian membuktikan bahwa financial distress berpengaruh negatif terhadap penerimaan opini audit going concern.

Kondisi perusahaan digambarkan dengan rasio keuangan yang dapat menghasilkan informasi bahwa perusahaan mengalami masalah keuangan atau tidak. Financial distress merupakan faktor perusahaan yang banyak dipakai untuk 
memprediksi kelangsungan hidupnya (going concern) dan kebangkrutan yang akan terjadi. Kondisi financial distress yang dihadapi oleh perusahaan menandakan bahwa perusahaan tersebut sedang mehadapi masalah keuangan. Kondisi keuangan pada perusahaan menggambarkan tingkat kesehatan perusahaan yang dimana akan mengalami arus kas negatif, rasio keungan yang buruk, gagal dalam membayar hutang jangka pendek maupun jangka panjang, berkurangnya customer dan masalah lainnya. Hal tersebut akan mengarah pada kebangkrutan sehingga going concern perusahaan akan diragukan. Auditor akan memperhatikan informasi tersebut sebagai signal yang akan ditindak lanjuti untuk mengevaluasi rencana dan tindakan manajemen untuk mengatasi masalah keuangan tersebut. Dalam menjalankan tugasnya, manajemen akan dihadapkan pada kondisi perusahaan yang berpengaruh terhadap kelangsungan suatu.

Kelangsungan hidup yang terganggu, menandakan keadaan keuangan perusahaan tersebut yang buruk (financial distress) apabila semakin baik perusahaan (tidak mengalami kesulitan keuangan), maka akan semakin kecil kemungkinan auditor mengeluarkan opini audit going concern, begitupun sebaliknya, apabila perusahaan semakin memburuk (mengalami kesulitan keuangan) maka akan besar kemungkinan perusahaan menerima opini audit going concern. Auditor tidak pernah memberikan opini audit going concern pada perusahaan yang siklus keuangan dan operasionalnya bagus, sehingga perusahaan yang mengalami masalah keuangan, kesulitan likuiditas, kekurangan modal kerja, dan secara terus menerus mengalami kerugian berpeluang mendapatkan opini audit going concern karena auditor meragukan kelangsungan perusahaan tersebut dapat bertahan dalam waktu yang lama.

\subsection{Model Analisis dan Hipotesis}

\subsubsection{Model Analisis}

Mengacu pada kerangka teoritis yang penulis susun maka dapat di kemukakan model analisis seperti yang tercantum pada gambar berikut : 


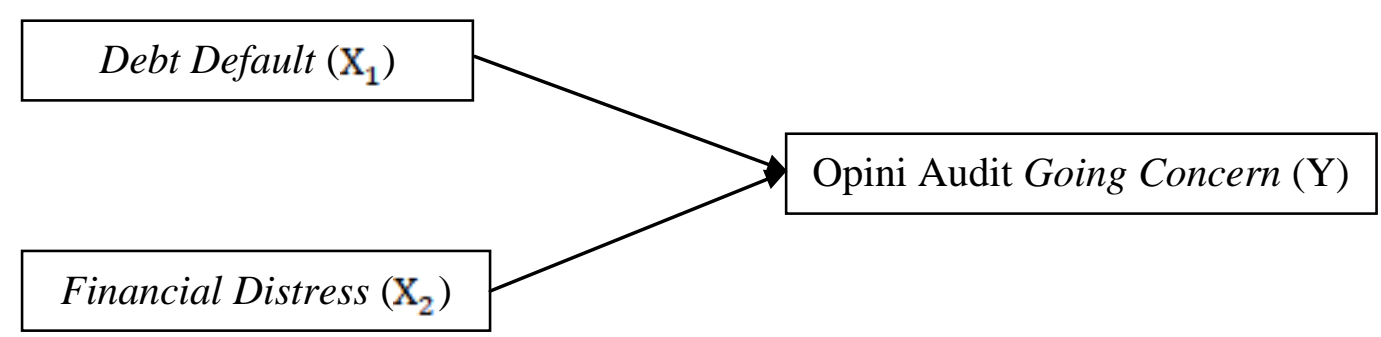

GAMBAR 2.1. Model Analisis

\subsubsection{Hipotesis}

Berdasarkan kerangka teoritis, dapat dikemukakan hipotesis dalam penelitian adalah sebgai berikut :

$\mathrm{H}_{1}$ : Debt default memiliki pengaruh positif terhadap penerimaan opini audit going concern.

$\mathrm{H}_{2}$ : Financial distress memiliki pengaruh negatif terhadap penerimaan opini audit going concern.

\section{METODE PENELITIAN}

\subsection{Populasi dan Sampel}

Penelitian ini dilakukan pada perusahaan yang memperoleh opini going concern dan opini non going concern dari auditor dengan time series penelitian selama 3 tahun yaitu periode Januari 2014 sampai dengan Desember 2016 pada perusahaan industri sektor pertambangan yang terdaftar di Bursa Efek Indonesia (BEI).

Berdasarkan data yang diperoleh dari IDX periode 2014 sampai dengan 2016, maka diperoleh populasi untuk penelitian ini adalah sebanyak 45 perusahaan.

Pemilihan sampel penelitian menggunakan purposive sampling dengan kriteria yang dipertimbangkan dalam pengambilan sampel penelitian adalah sebagai berikut :

1. Perusahaan industri pertambangan yang sudah terdaftar di Bursa Efek Indonesia selama periode 2014-2016 dan tidak di delisting.

2. Perusahaan industri pertambangan yang telah mempublikasikan seluruh laporan keuangan secara lengkap.

3. Perusahaan industri pertambangan yang melampirkan laporan auditor independen selama periode pengamatan tahun 2014 sampai 2016. 
TABEL 1. Proses Pemilihan Sampel

\begin{tabular}{|c|l|c|}
\hline No & \multicolumn{1}{|c|}{ Kriteria } & $\begin{array}{c}\text { Jumlah } \\
\text { Perusahaan }\end{array}$ \\
\hline 1. & $\begin{array}{l}\text { Perusahaan industri pertambangan yang terdaftar di } \\
\text { Bursa Efek indonesia selama periode 2014-2016 }\end{array}$ & 45 \\
\hline 2. & $\begin{array}{l}\text { Perusahaan yang tidak terdaftar secara berturut-turut } \\
\text { selama periode 2014-2016 }\end{array}$ & $(7)$ \\
\hline 3. & $\begin{array}{l}\text { Perusahaan yang tidak melampirkan laporan auditor } \\
\text { independen pada laporan keuangan yang akan diamati }\end{array}$ & $(1)$ \\
\hline \multicolumn{2}{r}{ Jumlah Sampel Akhir } & 37 \\
\hline & Tahun Pengamatan & 111 \\
\hline
\end{tabular}

\subsection{Pengukuran Variabel}

\section{Debt Default}

Debt default adalah kegagalan debitor (perusahaan) dalam membayar utang pokok atau bunganya pada waktu jatuh tempo (Chen dan Church, 2002; Praptitorini, 2007; Werastuti, 2013). Status debt default dilihat pada laporan keuangan perusahaan bagian laporan auditor independen pada paragraf penjelas (Susanto dan Zubaidah, 2015).

Debt default diukur menggunakan variabel dummy, digunakan 1 apabila berstatus debt default dan 0 apabila tidak debt default untuk menunjukan apakah perusahaan dalam keadaan default atau tidak sebelum pengeluaran opini audit, status debt default biasanya ada atau terungkap di catatan atas laporan keuangan pada penjelas atas laporan keuangan (pada pos utang) atau dalam opini audit.

Ghozali (2016:172) menyebutkan bahwa permasalahan yang sering dihadapi adalah adanya variabel independen yang berkala ukuran non-metrik atau kategori. Jika variabel independen berukuran kategori atau dikotom, maka dalam model regresi variabel tersebut harus dinyatakan sebagai variabel dummy dengan memberikan kode 0 (nol) atau 1 (satu). Cara pemberian kode dummy umumnya menggunakan kategori yang dinyatakan dengan angka 1 atau 0 . Kelompok yang diberi nilai dummy 0 (nol) disebut excluded group, sedangkan kelompok yang diberi nilai 1 (satu) disebut included group.

\section{Financial Distress}

Purwati dan Yuliandhari (2014), mendefinisikan financial distress merupakan tahapan kondisi keuangan suatu perusahaan sebelum terjadinya kebangkrutan atau 
likuidasi. Kebangkrutan biasanya diartikan sebagai kegagalan perusahaan dalam menjalankan operasi perusahaan untuk menghasilkan laba (Aminah dan Sanjaya, 2013).

Ketika suatu perusahaan mengalami kesulitan keuangan bahkan kegagalan bisnis hingga terancam akan bangrut maka perusahaan tersebut diyakini mengalami masalah, sehingga perusahaan tersebut diragukan dalam mempertahankan kelangsungan hidupnya (Yuliani dan Erawati, 2017). Altman dan McGough (1974) dalam Yuliani dan Erawati (2017) mengemukakan bahwa terdapat suatu model prediksi mencapai tingkat keakuratan $82 \%$ untuk memprediksi tingkat kebangkrutan dan menyarankan penggunaan model prediksi kebangkrutan sebagai alat bantu auditor untuk memutuskan kemampuan perusahaan mempertahankan kelangsungan hidupnya. Model prediksi kebangkrutan yang dimaksud adalah model prediksi kebangkrutan Revised Altman, yang dikenal dengan istilah Z-Score model (Yuliani dan Erawati, 2017). Dalam perhitungannya financial distress menggunakan model prediksi kebangkrutan Altman revisi yaitu semakin kecil nilai Z-Score, perusahaan semakin mengalami financial distress. Maka dapat dikatakan bahwa perusahaan yang mengalami financial distress dengan nilai Z-Score semakin kecil, maka besar kemungkinan menerima opini audit going concern.

Pada penelitian ini, financial distress dapat dianalisis menggunakan rumus Altman Z-Score untuk perusahaan non manufakrur yang telah go public dengan rumus sebagai berikut :

$$
Z=6,56 X_{1}+3,26 X_{2}+6,72 X_{3}+1,05 x_{4}
$$

Dimana :

$\mathrm{X}_{1}=$ Working Capital/Total Assets

$\mathrm{X}_{2}=$ Retainded Earnings/Total Assets

$\mathrm{X}_{3}=$ Earnings before Interest and Taxes/Total Assets

$\mathrm{X}_{4}=$ Maket Value of Equity/Book Value of Total Liabilities

$Z \quad=$ Overall Index or Score

Menurut munawir (2002:309) dalam Aminah dan Sanjaya (2013) interprestasi penilaian model Altman Z-Score yaitu :

1. Z-Score $>2,99$ artinya perusahaan tersebut dalam kondisi sehat dan tidak sedang mengalami kesulitan keuangan. 
2. $1,81<Z$-Score $<2,99$ artinya perusahaan memiliki peluang mengalami kebangkrutan namunpeluang terselamatkan dan peluang bangkrut sama besarnya, tergantung dari penanganan pihak manajemen dalam mengelola perusahaan mengatasi hal tersebut.

3. Z-Score $<1,81$ artinya perusahaan sedang dalam kondisi mengalami kesulitan keuangan yang pelik dan memiliki peluang besar akan menghadapi kebangkrutan.

\section{Opini Audit Going Concern}

Opini audit going concern diukur dengan menggunakan variabel dummy, yaitu apabila perusahaan yang terindikasi mendapatkan opini audit going concern diberi kode 1 (satu), sedangkan untuk perusahaan yang tidak terindikasi mendapatkan opini audit going concern atau non opini audit going concern diberi kode 0 (nol).

\subsection{Pengujian Hipotesis}

Analisis data dalam penelitian dilakukan dengan menggunakan regresi logistik. Analisis logistik ini digunakan untuk mengetahui seberapa besar pengaruh variabel bebas terhadap variabel terikatnya (Putri et al., 2016). Pengujian dilakukan untuk melihat perusahaan tersebut mengalami "debt default dan financial distressi" atau tidak.

Regresi logistik adalah regresi yang digunakan untuk menguji sejauh mana probabilitas terjadinya variabel dependen dapat dipredksi dengan variabel independen (Ibrahim, 2015). Analisis logistik adalah salah satu alternatif terbaik untuk mengatasi keterbatasan teknik MDA yang dalam analisanya harus dilakukan secara terpisah antar masing-masing variabel. Regresi logistik ini digunakan untuk menguji apakah probabilitas terjadinya variabel dependen dapat diprediksi dengan variabel independen. Teknik analisis ini tidak memerlukan lagi uji normalitas dan uji asumsi klasik pada variabel independennya. Regresi logistik mengabaikan heteroscedasity, artinya variabel dependen tidak memerlukan homoscedacity untuk masing-masing variabel independennya (Siregar dan Rahman, 2012). 
Model umum regresi logistik dirumuskan dengan persamaan sebagai berikut :

$$
\mathrm{Y}=\alpha+\beta_{1} \mathrm{X}_{1}-\beta_{2} \mathrm{X}_{2}+\mathrm{e}
$$

Dimana :

$$
\begin{array}{ll}
\mathrm{Y} & =\text { Opini audit going concern } \\
\alpha & =\text { Konstanta } \\
\beta & =\text { Koefesien Regresi } \\
\mathrm{X}_{1} & =\text { Debt default } \\
\mathrm{X}_{2} & =\text { Financial Distress } \\
\mathrm{e} & =\text { Error }
\end{array}
$$

Untuk menjadikan model tersebut linier, proses transformasi yang dinamakan logit transformation perlu Menggunakankan persamaan sebagai berikut :

$$
\operatorname{Ln}\left(\frac{\text { OAGC }}{1-\text { OAGC }}\right)=\mathrm{a}+\beta 1 D D+\beta 2 \text { ALTMAN }+\mathrm{e}
$$

Dimana :

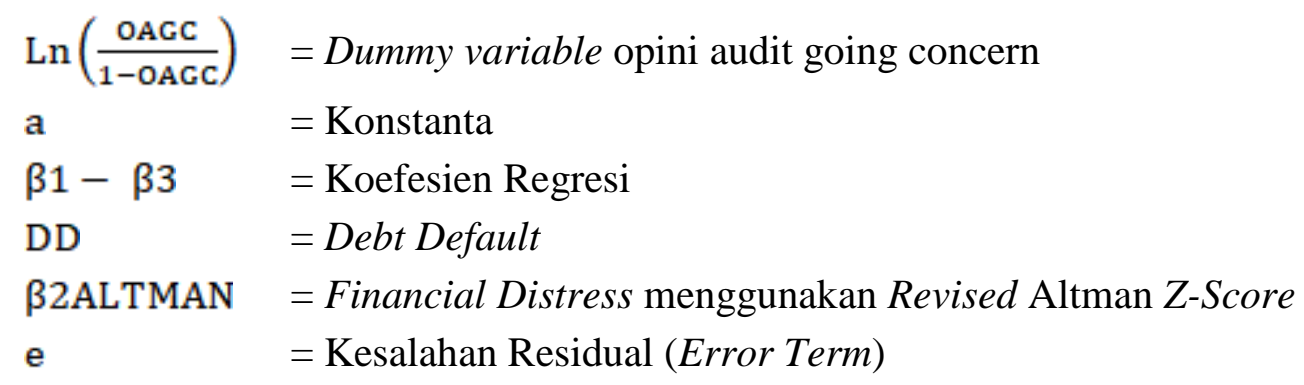

\section{HASIL PENELITIAN DAN PEMBAHASAN}

Penelitian ini menggunakan sampel perusahaan industri pertambangan yang terdaftar di Bursa Efek Indonesia (BEI) selama periode 2014 sampai dengan 2016. Teknik pengambilan sampel yang digunakan dalam penelitian ini adalah teknik purposive sampling. Berdasarkan kriteria yang telah ditetapkan maka diperoleh sebanyak 37 sampel perusahaan dengan periode pengamatan selama 3 tahun yang selanjutnya akan digunakan sebagai sumber data untuk analisis, sehingga diperoleh sebanyak 111 data atau sampel amatan. 


\subsection{Menilai Kelayakan Model Regresi}

Kelayakan model regresi dinilai dengan nilai Cox dan Snell's R Square, ChiSquare yang terdapat dibawah uji Hosmer and Lemeshow Goodness off Fit Tes. Model ini menguji hipotesis data empiris apakah cocok atau sesuai dengan model (tidak ada perbedaan antara model dengan data sehingga model dapat dikatakan fit).

Kemudian ukuran Cox dan Snell's R Square merupakan ukuran yang mencoba meniru ukuran $\mathrm{R}^{2}$ pada multiple regression yang didasarkan pada teknik estimasi likelihood dengan nilai maksimum kurang dari 1 (satu) sehingga sulit diinterprestasikan. Nagelkerke's R square merupakan modifikasi dari koefesien Cox dan Snell's R Square untuk memastikan bahwa nilainya bervarisi dari 0 (nol) sampai 1 (satu). Hal ini dilakukan dengan cara membagi nilai Cox dan Snell's $\mathrm{R}^{2}$ Square dengan nilai maksimumnya. Nilai nagelkerke's $\mathrm{R}^{2}$ dapat diinterprestasikan seperti nilai $\mathrm{R}^{2}$ pada multiple regression.

Sedangkan Hosmer and Lemeshow's Goodness off Fit Test menguji hipotesis nol bahwa data empiris cocok atau sesuai dengan model (tidak ada perbedaan antara model dengan data sehingga model dapat dikatakan fit). Adapun hasilnya yang dijelaskan antara lain :

a. Jika nilai Goodness off Fit Test yang diukur dengan nilai chi-square > 0,05 maka H0 diterima.

b. Jika nilai Goodness off Fit Test yang diukur dengan nilai chi-square $<0,05$ maka H0 ditolak.

TABEL 2. Overall Model Fit - Awal

\begin{tabular}{|c|c|c|c|}
\hline \multicolumn{2}{|c|}{ Iteration } & $\begin{array}{l}-2 \text { Log } \\
\text { likelihood }\end{array}$ & Coefficients \\
\hline \multirow[t]{4}{*}{ Step 0} & 1 & 102,762 & $-1,315$ \\
\hline & 2 & 101,624 & $-1,558$ \\
\hline & 3 & 101,618 & $-1,577$ \\
\hline & 4 & 101,618 & $-1,577$ \\
\hline
\end{tabular}

Sumber : data output SPSS

a. Constant is included in the model.

b. Initial -2 Log Likelihood: 101,618

c. Estimation terminated at iteration number 4 because parameter estimates changed by less than, 001 . 
TABEL 3. Overall Model Fit - Akhir

\begin{tabular}{|c|c|c|c|c|c|}
\hline \multirow{2}{*}{\multicolumn{2}{|c|}{ Iteration }} & \multirow{2}{*}{$\begin{array}{c}-2 \log \\
\text { likelihood }\end{array}$} & \multicolumn{3}{|c|}{ Coefficients } \\
\hline & & & Constant & DD & FD \\
\hline \multirow{7}{*}{$\begin{array}{l}\text { Step } \\
1\end{array}$} & & 96,267 & $-1,338$ & , 423 &,- 028 \\
\hline & 2 & 86,521 & $-1,410$ & ,453 &,- 103 \\
\hline & 3 & 79,266 & $-1,135$ & ,090 &,- 242 \\
\hline & 4 & 77,742 & $-1,064$ &,- 133 &,- 333 \\
\hline & 5 & 77,667 & $-1,058$ &,- 188 &,- 359 \\
\hline & 6 & 77,666 & $-1,058$ &,- 191 &,- 360 \\
\hline & 7 & 77,666 & $-1,058$ &,- 191 &,- 360 \\
\hline
\end{tabular}

Sumber : data output SPSS

a. Constant is included in the model.

b. Initial -2 Log Likelihood: 101,618

c. Estimation terminated at iteration number 4 because parameter estimates changed by less than ,001.

Berdasarkan tabel 2 dan 3 dapat dilihat bahwa nilai -2 Log Likelihood awal sebesar 102,762, sedangkan untuk -2 Log Likelihood akhir adalah sebesar 96,267. Hal ini menunjukan bahwa nilai -2 Log Likelihood (block number $=0$ ) $>$ nilai -2 Log Likelihood (block number $=1$ ), atau nilai 102,762 > 96,267. Artinya keseluruhan model menunjukan model regresi yang baik, karena nilai -2 Log Likelihood dalam penelitian ini mengalami penurunan.

\subsection{Hosmer and Lemeshow's Goodness of Fit Tes}

TABEL 4. Hosmer and Lemeshow Test

\begin{tabular}{|c|r|r|r|}
\hline Step & Chi-square & df & Sig. \\
\hline 1 & 9,096 & &, 334 \\
\hline
\end{tabular}

Sumber : Hasil Output SPSS

Berdasarkan tabel 4 dapat dilihat bahwa nilai Chi-Squre yang merupakan hasil dari Hosmer and Lemeshow's Goodness of Fit menunjukan angka sebesar 9,069 dengan tingkat signifikansi sebesar 0,334 >0,05. Berarti H0 diterima. Hal ini menunjukan bahwa model yang dihipotesiskan fit dengan data atau model dapat diterima karena cocok dengan data observasinya. 


\subsection{Pengujian Hipotesis}

Pengujian dengan model regresi logistik digunakan dalam penelitian ini adalah untuk mengetahui pengaruh dari masing-masing variabel independen terhadap variabel dependen.

TABEL 5. Uji Hipotesis

\begin{tabular}{|ll|r|r|r|r|r|r|}
\hline & & \multicolumn{1}{|c|}{ B } & \multicolumn{1}{c|}{ S.E. } & \multicolumn{1}{c|}{ Wald } & \multicolumn{1}{c|}{ df } & \multicolumn{1}{c|}{ Sig. } & Exp(B) \\
\hline Step & DD &,- 191 &, 629 &, 093 & 1 &, 761 &, 826 \\
1(a) & FD &,- 360 &, 104 & 11,936 & 1 &, 001 &, 697 \\
& Constan & $-1,058$ &, 403 & 6,905 & 1 &, 009 &, 347 \\
& t & & & & & 1 & \\
\hline
\end{tabular}

Sumber : Hasil Output SPSS

Berdasarkan tabel 5 menunjukan hasil pengujian dengan regresi logistik pada tingkat signifikan kurang dari 0,05. Dari pengujian dengan regresi logistik maka diperoleh persamaan regresi logistik sebagai berikut :

$$
\operatorname{Ln}\left(\frac{\text { OAGC }}{1-\text { OAGC }}\right)=a+\beta 1 D D+\beta 2 \text { ALTMAN }+e
$$

Dimana :

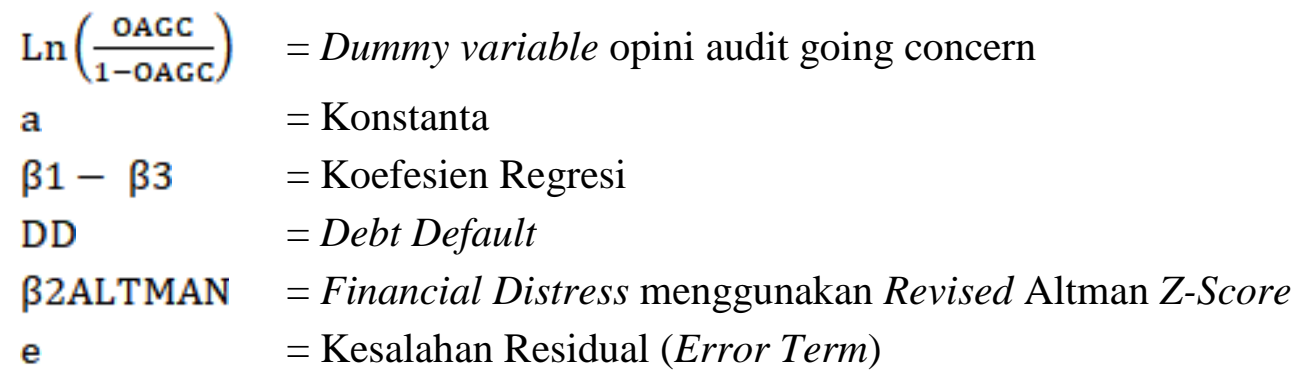

Berdasarkan hasil pengujian regresi logistik, variabel debt default (DD) menunjukan nilai koefesien negatif sebesar -0,191 dengan tingkat signifikan 0,761 yaitu lebih besar dari 0,05 (5\%). Sehingga dapat disimpulkan bahwa debt default berpengaruh negatif tidak signifikan terhadap penerimaan opini audit going concern, artinya variabel debt default tidak memiliki pengaruh terhadap variabel independen. Dengan kata lain H1 ditolak. karena hipotesis yang diajukan dalam penelitian ini adalah debt default berpengaruh positif terhadap opini audit going concern.

Variabel lain yang diproksikan dengan rumus Altman Z-Score yaitu financial distress (FD) menunjukan nilai koefesiensi negatif sebesar -0,360 dengan tingkat signifikan sebesar 0,001 yang lebih kecil dari 0,05. Artinya, dapat disimpulkan bahwa 
H2 diterima dan mendukung hipotesis yang diajukan yaitu financial distress berpengaruh negatif terhadap penerimaan opini audit going concern.

\subsection{Pengujian Secara Simultan}

Pengujian ini dilakukan dengan melihat Omnibus of Model Coefficients dengan hipotesis sebagai berikut :

1. $\mathrm{H} 0: \alpha>0,05$ berarti variabel debt default dan financial distress secara simultan atau secara bersama-sama berpengaruh tidak signifikan terhadap opini audit going concern.

2. $\mathrm{H}_{1}: \alpha<0,05$ berarti variabel debt default dan financial distress secara simultan atau secara bersama-sama berpengaruh terhadap opini audit going concern.

TABEL 6. Omnibus Tests of Model Coefficients

\begin{tabular}{|ll|r|r|r|}
\hline & & Chi-square & \multicolumn{1}{c|}{ df } & \multicolumn{1}{c|}{ Sig. } \\
\hline Step 1 & Step & 23,952 & 2 &, 000 \\
& Block & 23,952 & 2 &, 000 \\
& Model & 23,952 & 2 &, 000 \\
\hline
\end{tabular}

Sumber : Hasil Output SPSS

Setelah dilakukan pengujian secara simultan, dapat dilihat dari tabel 6 yaitu tabel Omnibus Tests of Model Coefficient, bahwa didapat besarnya nilai signifikansi (Sig.) adalah sebesar 0,000. Karena nilai tersebut lebih kecil dari 0,05 berarti H0 diterima, artinya variabel debt default dan financial distress secara simultan atau secara bersamasama berpengaruh terhadap opini audit going concern.

\subsection{Tabel Klasifikasi}

Tabel klasifikasi menunjukan seberapa kuat model regresi dalam memprediksi probabilita penerimaan opini audit going concern. Kekuatan prediksi tersebut dinyatakan dalam presentase. 
TABEL 7. Classification Table (a)

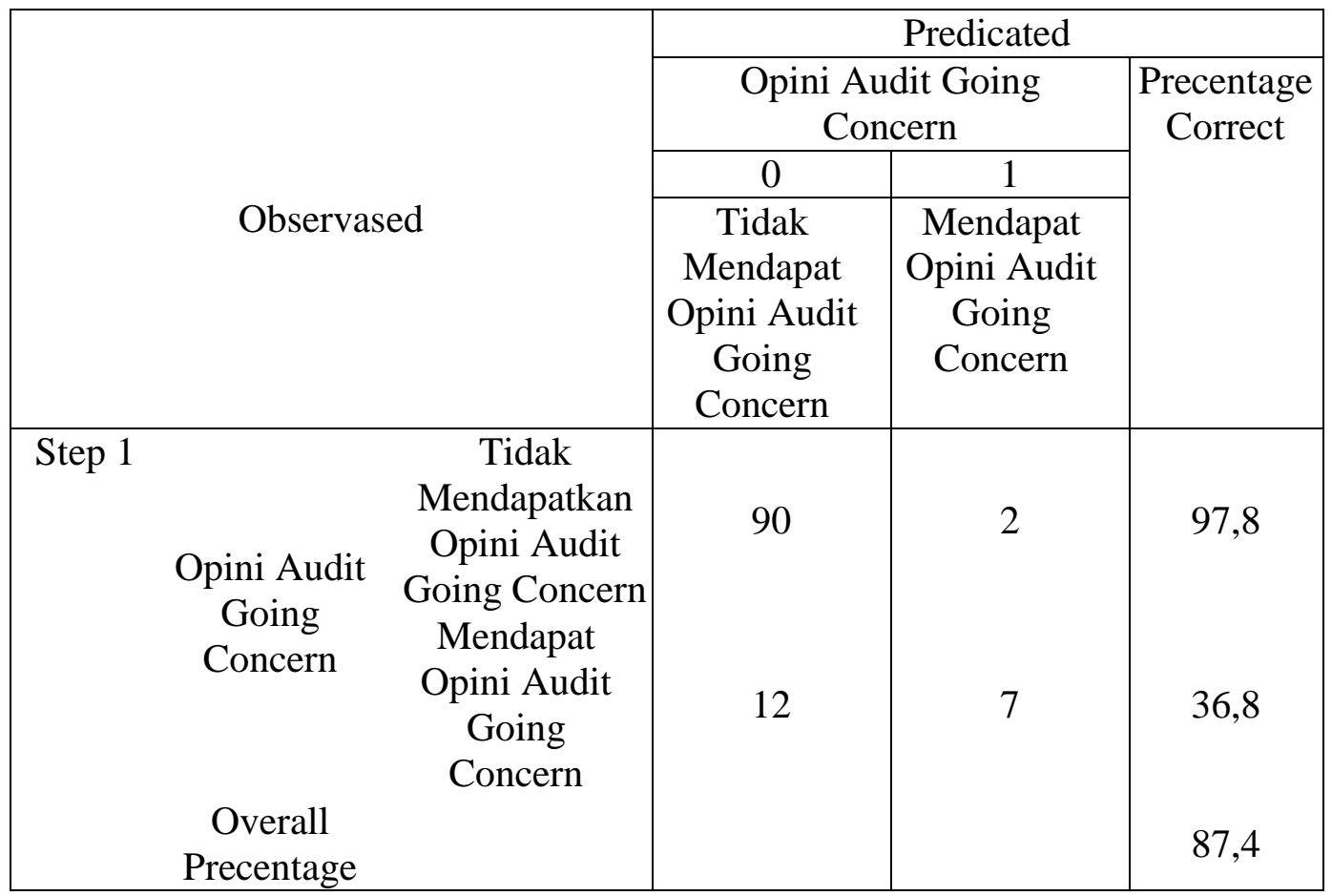

Sumber : Hasil Output SPSS

Berdasarkan tabel 7 yaitu tabel klasifikasi menunjukan kekuatan prediksi dan model regresi untuk memprediksi kemungkinan mendapatkan opini audit going concern pada auditee adalah sebesar 36,8\%. Hal ini menunjukan bahwa dengan menggunakan model regresi yang diajukan, dari total 19 auditee, terdapat 7 auditee yang diprediksi mendapat opini audit going concern.

Sedangkan kekuatan model regresi untuk memprediksi kemungkinan mendapat opini audit going concern atau tidak mendapat opini audit going concern adalah sebesar $97,8 \%$. Berarti dengan model regresi yang diajukan dari total 92 auditee, terdapat 2 auditee yang diprediksi mendapat opini audit going concern dan 90 auditee lainnya diprediksi tidak mendapat opini audit going concern.

\subsection{Koefesien Determinasi (Nagelkerke $R$ Square)}

Nagelkerke $R$ Square merupakan pengujian yang dilakukan untuk mengetahui seberapa besar variabel independen mampu menjelaskan dan mempengaruhi variabel dependen. Nilai Nagelkerke $R$ Square dapat diinterprestasikan seperti nilai $R$ Square pada regresi berganda. Nilai didapat dengan cara membagi nilai Cox \& Snell $R$ Square dengan nilai maksimumnya. 
TABEL 8. Koefesien Determinasi (Nagelkerke R Square)

Model Summary

\begin{tabular}{|c|c|c|c|}
\hline Step & $\begin{array}{c}-2 \text { Log } \\
\text { likelihood }\end{array}$ & $\begin{array}{c}\text { Cox \& Snell R } \\
\text { Square }\end{array}$ & $\begin{array}{c}\text { Nagelkerke R } \\
\text { Square }\end{array}$ \\
\hline 1 & $77,666(a)$ &, 194 &, 324 \\
\hline
\end{tabular}

Sumber : Hasil Output SPSS

Berdasarkan tabel 8 dapat dilihat bahwa nilai Nagelkerke $R$ Square adalah sebesar 0,324. Hal ini menunjukan bahwa opini audit going concern dapat dijelaskan oleh debt default dan financial distress sebesar 32,4\%. Dan sisa nya sebesar 67,6\% dijelaskan oleh faktor lain diluar penelitian ini seperti misalnya kondisi keuangan, ukuran perusahaan dan opinion shopping (Dewi, 2011), dan masih banyak lagi faktor lainnya.

\subsection{Pembahasan}

Hasil penelitian ini memberikan gambaran yang ditunjukan dari rujukan penlitian terdahulu dengan temuan penelitian yang sedang diteliti. Dari hasil penelitian pada perusahaan industri pertambangan periode 2014 sampai dengan 2016 dapat diketahui bahwa hasil perhitungan statistik menggunakan regresi logistik pengujian secara simultan menunjukan variabel debt default dan financial distress secara bersama-sama berpengaruh signifikan terhadap penerimaan opini audit going concern. Hal ini dibuktikan dengan nilai Chi-square sebesar 23,952 dengan tingkat signifikan 0,000 yang lebih kecil dari tingkat signifikan yang digunakan yaitu 0,05 .

Berdasarkan hasil pengujian regresi logistik, variabel debt default (DD) menunjukan nilai koefesien negatif sebesar -0,191 dengan tingkat signifikan 0,761 yaitu lebih besar dari 0,05 (5\%). Sehingga dapat disimpulkan bahwa debt default berpengaruh negatif tidak signifikan terhadap penerimaan opini audit going concern. Dengan kata lain H1 ditolak atau hipotesis yang diajukan tidak dapat dikonfirmasi. Karena hipotesis yang diajukan dalam penelitian ini adalah debt default berpengaruh positif terhadap opini audit going concern.

Hasil penelitian ini tidak mendukung penelitian yang telah dilakukan oleh Praptitorini dan Januarti (2011), Nirmalasari (2014), Sandi et al., (2014), Imani et al., (2017) dan Suharsono (2018) yang membuktikan bahwa debt default berpengaruh positif dan signifikan terhadap opini audit going concern. 
Namun hasil penelitian ini mendukung temuan Susanto (2009), Nanda dan Siska (2015) dan Lestari (2016) yang menyatakan bahwa debt default tidak berpengaruh signifikan terhadap penerimaan opini audit going concern.

Tidak berpengaruhnya debt default terhadap opini audit going concern karena dari hasil penelitian menunjukkan bahwa mayoritas auditee memiliki kemampuan dalam membayar hutang yang baik sebelum jatuh tempo atau digolongkan kedalam perusahaan yang stabil namun terdapat beberapa auditee diantaranya yang mendapatkan opini audit going concern dan terdapat auditee yang memiliki status debt default atau kegagalan debitor (perusahaan) dalam membayar utang pokok atau bunganya pada waktu jatuh tempo tetapi tidak mendapatkan opini audit going concern sehingga memperjelas hasil penelitian ini bahwa debt default tidak memiliki pengaruh yang kuat terhadap pemberian opini audit going concern.

Hasil penelitian Susanto (2009) menyatakan bahwa auditor dalam memberikan opini audit going concern tidak hanya berdasarkan debt default, akan tetapi lebih cenderung melihat kondisi keuangan perusahaan secara keseluruhan.

Pernyataan tersebut didukung oleh Mery Christins (2012) dalam Nanda dan Siska (2015) yang menyatakan bahwa auditor dalam memberikan opini audit going concern tidak hanya didasarkan pada keadaan perusahaan yang gagal (default) dalam memenuhi kewajibannya, maupun perusahaan yang tidak dapat memenuhi perjanjian hutang atau sedang berada pada kondisi rektrukturisasi hutang, tetapi auditor lebih mempertimbangkan kondisi perusahaan yang mengalami kerugian operasi yang berulang kali terjadi sejak tahun-tahun sebelumnya, defisit, dan juga dipengaruhi oleh signifikan atau tidaknya kondisi tersebut tergantung atas keadaan, misalnya kondisi yang terjadi mengakibatkan pembangunan perusahaan terbatas atau kegiatan usahanya terhambat, kesulitan merealisasikan aktiva dan menyelesaikan kewajibannya.

Dalam penelitian ini, financial distress diukur dengan menggunakan model ZScore. Variabel financial distress (FD) menunjukan nilai koefesien negatif sebesar 0,360 dengan tingkat signifikan ,001 yaitu lebih kecil dari 0,05 (5\%). Maka hipotesis H2 yang menyatakan bahwa variabel financial distress berpengaruh negatif terhadap penerimaan opini audit going concern berhasil didukung atau hipotesis yang diajukan dapat dikonfirmasi. Dengan demikian dapat disimpulkan bahwa variabel financial distress berpengaruh negatif signifikan terhadap penerimaan opini audit going concern. 
Hasil penelitian tidak sejalan dengan penelitian yang dilakukan oleh Fauziyah (2015) dan Kesumojati et al., (2017) menyimpulkan bahwa variabel financial distress berpengaruh positif signifikan terhadap penerimaan opini audit going concern.

Namun penelitian ini konsisten dengan hasil penelitian yang dilakukan oleh Sidqi dan Sutapa (2014), Juliana (2013) dan Hasanah (2015) yang membuktikan bahwa variabel financial distress berpengaruh negatif terhadap penerimaan opini audit going concern.

Berpengaruhnya financial distress terhadap opini audit going concern karena dari hasil penelitian menunjukkan bahwa auditee yang mengalami financial distress atau kesulitan keuangan mendapatkan opini audit going concern yang artinya terdapat pengaruh buruk terhadap perusahaan. Juliana (2013) berpendapat bahwa kesangsian terhadap kelangsungan hidup perusahaan merupakan indikasi terjadinya kebangkrutan pada perusahaan. Sehingga memperjelas hasil penelitian ini bahwa financial distress berpengaruh negatif signifikan terhadap opini audit going concern.

Kondisi perusahaan yang baik mengindikasikan bahwa perusahaan tersebut memiliki kemampuan untuk melanjutkan usahanya di masa depan, sehingga kecil kemungkinan auditor memberikan opini audit going concern, sebaliknya pada perusahaan yang kondisi keuangannya buruk, mengindikasikan bahwa perusahaan tersebut mengalami ketidakpastian dalam kemampuan menjalankan usahanya di masa depan, maka auditor akan semakin besar kemungkinan untuk memberi opini audit going concern (Sidqi dan Sutapa, 2014). Mc Keown et al., (1991) dalam Setyarno (2006) berpendapat bahwa auditor hampir tidak pernah memberikan opini audit going concern pada perusahaan yang tidak mengalami kesulitan keuangan.

Fauziah (2015) menyatakan bahwa jika laba menurun dengan ketentuan tertentu maka perusahan dapat dikatagorikan sebagai perusahaan yang distress. Dalam kondisi yang sulit, ada perusahaan yang dapat mempertahankan kelangsungan usahanya dan tidak. Karena itu, jika ada indikasi kesulitan keuangan, auditor akan cenderung memberikan opini going concern.

Financial distress merupakan faktor perusahaan yang banyak dipakai untuk memprediksi going concern atau keberlangsungan hidup perusahaan dan kebangkrutan yang akan terjadi (Juliana, 2013). 
Kondisi keuangan perusahaan menggambarkan tingkat kesehatan perusahaan sesungguhnya. Kondisi kesulitan keuangan akan menyebabkan perusahaan mengalami arus kas negatif, rasio keuangan yang buruk dan gagal membayar hutang. Pada akhirnya, kesulitan keuangan ini akan mengarah kepada kebangkrutan sehingga going concern perusahaan diragukan (Hasanah, 2015).

Mckeown et. al (1991) dalam Hasanah (2015) menyatakan bahwa semakin kondisi perusahaan terganggu atau memburuk maka akan semakin besar kemungkinan perusahaan menerima opini audit going concern. Sebaliknya pada perusahaan yang tidak pernah mengalami kesulitan keuangan auditor tidak pernah mengeluarkan opini audit going concern. Hal ini konsisten dengan bukti empiris yang menyatakan bahwa semakin kondisi keuangan perusahaan terganggu atau memburuk, maka akan semakin besar probabilitas perusahaan menerima opini going concern. Dan sebaliknya pada perusahaan yang memiliki kondisi keuangan yang sehat, maka probabilitas untuk menerima opini audit going concern akan semakin kecil.

\section{SIMPULAN DAN SARAN}

Penelitian ini bertujuan untuk memberikan bukti empiris mengenai pengaruh debt default dan financial distress terhadap opini audit going concern dengan populasi perusahaan industri pertambangan sektor pertambangan, minyak dan gas bumi, logam dan mineral, serta batu-batuan, yang terdaftar di Bursa Efek Indonesia (BEI) tahun 2012 sampai dengan tahun 2016. Sampel akhir pada penelitian ini adalah 37 perusahaan dengan periode pengamatan selama 3 tahun, sehingga diperoleh sebanyak 111 sampel amatan.

Berdasarkan hasil penelitian yang telah dilakukan, serta melalui berbagai rangkaian mulai dari pengumpulan data, pengolahan data, analisis data dan interpretasi hasil analisis mengenai debt default dan financial distress maka dapat ditarik kesimpulan sebagai berikut :

1. Pengaruh debt default terhadap opini audit going concern.

Hasil pengujian hipotesis H1 menyatakan bahwa debt default berpengaruh negative dan tidak signifikan terhadap opini audit going concern. Dengan kata lain status debt default bukan alasan utama yang menjadikan laporan keuangan atau perusahaan diragukan keberlangsungan usahanya, karena auditee bisa 
memperpanjang waktu jatuh tempo dalam membayar hutang dan bunga nya sehingga auditor tidak memberikan opini audit going concern. Auditor dalam memberikan opini audit going concern tidak hanya berdasarkan debt default, akan tetapi lebih cenderung melihat kondisi keuangan perusahaan secara keseluruhan. Hal ini disebabkan status debt default belum tentu perusahaan tersebut akan mengalami kebangkrutan. Maka dari itu auditor akan mempertimbangkan faktor lain dalam memberikan opini audit going concern pada perusahaan.

2. Pengaruh financial distress terhadap opini audit going concern.

Hasil pengujian hipotesis $\mathrm{H} 2$ menyatakan bahwa financial distress yang diproksikan dengan model prediksi kebangkrutan Altman Z-Score secara statistik berpengaruh berpengaruh negatif dan signifikan terhadap opini audit going concern. Dengan kata lain, apabila perusahaan yang dilihat dari laporan keuangan semakin memburuk (mengalami kesulitan keuangan) maka akan besar kemungkinan auditor meragukan keberlangsungan usahanya. Kondisi perusahaan yang baik mengindikasikan bahwa perusahaan tersebut memiliki kemampuan untuk melanjutkan usahanya di masa depan, sehingga kecil kemungkinan auditor memberikan opini audit going concern, sebaliknya pada perusahaan yang kondisi keuangannya buruk, mengindikasikan bahwa perusahaan tersebut mengalami ketidakpastian dalam kemampuan menjalankan usahanya di masa depan, maka auditor akan semakin besar kemungkinan untuk memberi opini audit going concern.

\section{DAFTAR PUSTAKA}

Agoes, Sukrisno. 2016. Auditing : Petunjuk Praktis Pemeriksaan Akuntan oleh Akuntan Publik. Salemba Empat, Jakarta.

2017. Auditing : Petunjuk Praktis Pemeriksaan Akuntan oleh Akuntan Publik. Salemba Empat, Jakarta.

Alamanda, Putri Karina. 2015. Pengaruh Ukuran Perusahaan, Profitabilitas, Solvabilitas Dan Debt Default Terhadap Penerimaan Opini Audit Going Concern.

Altman, Edward I., Erkki K. Laitinen., dan Arto Suvas. 2014. Distressed Firm And Bankruptcy Prediction In An International Context: A Review And Empirical Analysis Of Altman's Z-Score Model. Latest version, July 9, 2014. 
Aminah., Andi Sanjaya. 2013. Pengaruh Kebangkrutan Pada Perusahaan Perbankan.

Anam, Choirul., dan Alex Murtin. 2008. Pengaruh Kualitas Audit, Debt Default Dan Kondisi Keuangan Perusahaan Terhadap Penerimaan Opini Going Concern. Jurnal Akuntansi dan Investasi. Vol. 9 No. 2, Juli 2008. pp. 197-207.

Andre, Orina. 2014. Pengaruh Profitabilitas, Likuiditas, dan Leverage Dalam Memprediksi Financial Distress. Jurnal WRA. Vol. 2 No 1, April 2014.

Carolina, Verani. 2017. Analisis Rasio Keuangan untuk Memprediksi Kondisi Financial Distress. Jurnal Akuntansi Maranatha . Vol. 9 No. 2, November 2017, pp. 137-145.

Dwijayanti, Patricia Febrima. 2010. Penyebab, Dampak, Dan Prediksi Dari Financial Distress Serta Solusi Untuk Mengatasi Financial Distress. Jurnal Akuntansi Kontemporer. Vol. 2 No. 2, Juli 2010, pp. 191.205.

Fauziyah. 2015. Pengaruh Financial Distress Terhadap Opini Audit Going Concern. Cendekia Akuntansi Vol. 3 No. 3, September 2015.

Ghozali, Imam. 2016. Aplikasi Analisis Multivariate Dengan Program IBM SPSS 23. Semarang: Badan Penerbit Universitas Diponegoro.

Handayani, Fitri. 2015. Pengaruh Kualitas Audit, Debt Default, Pertumbuhan Perusahaan dan Opini Audit Sebelumnya Terhadap Penerimaan Opini Audit Going Concern.

Harris, Randy., dan Wahyu Merianto. 2015. Pengaruh Debt Default, Disclosure, Opini Audit Tahun Sebelumnya, Ukuran Perusahaan, Dan Opinion Shopping Terhadap Penerimaan Opini Audit Going Concern. Diponegoro Journal Of Accounting. Vol. 4 No. 3, Tahun 2015, pp. 1-11.

Hasanah, Uswatun. 2015. Pengaruh Kualitas Audit, Financial Distress, Dan Audit Lag Terhadap Penerimaan Opini Audit Going Concern.

Hatta, Atika Jauhari . 2002. Faktor-Faktor Yang Mempengaruhi Kebijakan Deviden: Investigasi Pengaruh Teori Stakeholder. JAAI Vol. 6 NO. 2, Desember 2002.

Ibrahim, Dicky Irawan. 2015. Pengaruh Debt Default, Kualitas Audit Dan Opini Audit Tahun Sebelumnya Terhadap Penerimaan Opini Audit Going Concern.

Ikatan Akuntan Indonesia - Kompartemen Akuntan Publik. Standar Professional Akuntan Publik, per 1 januari 2001. Penerbit Salemba Empat. Jakarta. 2001.

Ikhsan, Arfan., dan Herkulanus Bambang Suprasto. 2008. Teori Akuntansi \& Riset Multiparadigma. Graha Ilmu. 
Imani, Galan Khalid., Muhammad Rafki Nazar., dan Eddy Budiono. 2017. Pengaruh Debt Default, Audit Lag, Kondisi Keuangan, dan Opini Audit Tahun Sebelumnya Terhadap Penerimaan Opini Audit Going Concern. E-Proceeding of Management. Vol. 4, No. 2 Agustus 2017.

Islahuzzaman. 2012. Istilah-istilah Akuntansi. Graha ilmu

Istiana, Siti. 2010. Pengaruh Kualitas Audit, Opinion Shopping, Debt Default Pertumbuhan Perusahaan Dan Kondisi Keuangan Perusahaan Terhadap Penerimaan Opini Audit Going Concern. Jurnal Akuntansi \& Investasi. Vol. 11 No. 1, pp. 80-96.

Juliana, Winda. 2013. Pengaruh financial distress terhadap penerimaan opini audit going concern.

Kesumojati, Tri Widyastuti., dan Darmansyah. 2017. Pengaruh Kualitas Audit, Financial Distress, Debt Default Terhadap Penerimaan Opini Audit Going Concern. Jurnal Ilmiah Akuntansi Fakultas Ekonomi. Vol. 3 No. 1, pp. 63.

Krissindiastuti, Monica., dan Ni Ketut Rasmini. 2016. Faktor-Faktor Yang Mempengaruhi Opini Audit Going Concern. E-Jurnal Akuntansi Universitas Udayana. Vol. 14 No. 1, Januari 2016, pp. 451-481.

Lestari, Ela May. 2016. Pengaruh Kondisi Keuangan Perusahaan, Pertumbuhan Perusahaan, Debt Default Dan Opini Audit Tahun Sebelumnya Terhadap Penerimaan Opini Audit Going Concern.

Nanda, Fini Rizki., dan Siska. 2015. Pengaruh Audit Tenure, Disclosure, Ukuran Kap, Debt Default, Opinion Shopping Dan Kondisi Keuangan Terhadap Penerimaan Opini Audit Going Concern. Jurnal Ekonomi, Manajemen dan Akutansi. Vol. 24 No. 1, Juni 2015.

Nirmalasari, Oktavia Tri. 2014. Pengaruh Debt Default, Auditor Client Tenure, Kualitas Kap, Disclosure Dan Ukuran Perusahaan Terhadap Penerimaan Opini Audit Going Concern.

Noviantari, Ni Wayan., dan Ni Made Dwi Ratnadi. 2015. Pengaruh Financial Distress, Ukuran Perusahaan, dan Leverage Pada Konservatisme Akuntansi. E-Jurnal Akuntansi Universitas Udayana. Vol. 11 No. 3, pp. 646-660.

Nurhayati. 2017. Pengaruh Kualitas audit, dan Financial Distress terhapad Manajemen Akuntansi.

Nurnyaman., Veronica Christina. 2015. Metodologi Penelitian Akuntansi dan Bisnis. Yogyakarta. E-Proceeding of Management. Vo. 9 No. 1. 
Praptitorini, Mirna Dyah., dan Indira Januarti. 2011. Analisis Pengaruh Kualitas Audit, Debt Default dan Opinion Shopping Terhadap Penerimaan Opini Going Concern. Jurnal Akuntansi dan Keuangan Indonesia, Juni 2011, Volume 8 No. 1, 78-93.

. 2007. Analisis Pengaruh Kualitas Audit, Debt Default Dan Opinion Shopping Terhadap Penerimaan Opini Going C/ $\quad$ oncern. AUEP.

Purwanto, Agus. 2011. Pengaruh Tipe Industri, Ukuran Perusahaan, Profitabilitas, Terhadap Corporate Social Responsibility. Jurnal Akuntansi \& Auditing Vol. 8 No. 1, November 2011, pp. 1-94.

Purwati, Yani., dan Willy Sri Yuliandhari. 2014. Pengaruh Financial Distress, Opini Audit Tahun Sebelumnya, Dan Kualitas Audit Terhadap Penerimaan Opini Audit Modifikasi Going Concern.

Putry, Hafizah., dan Badrudin Mumtaz. 2017. Pengaruh Kinerja Keuangan Daerah Terhadap Opini Audit Dan Kesejahteraan Masyarakat. Jurnal Akuntansi \& Auditing Vol. 8 No. 1, pp. 80-96.

Putri, Galuh Prahastiwi., Ari Pranaditya., dan Kharis Rahardjo. 2016. Financial Condition, Size Companies, Debt Default Reputation Kap, Lag Audit And Audit Opinion On The Previous Year Audit Opinion Going Concern.

Susanto, Putri Ragillia., dan Siti Zubaidah. 2015. Pengaruh Kinerja Keuangan, Debt Default Dan Reputasi Kantor Akuntan Publik Terhadap Penerimaan Opini Audit Going Concern. Jurnal Reviu Akuntansi dan Keuangan. Vol. 5 No. 2, Oktober 2015, Pp. 791-800.

Rahayu, Siti Kurnia., dan Ely Suhayati. 2013. Auditing : Konsep Dasar dan Pedoman Pemeriksaan Akuntan Publik. Graha Ilmu, Jakarta.

Rahmat, Zulfikri. 2016. Pengaruh Debt Default, Disclosure, Audit Client Tenure,dan Audit Lag Terhadap Penerimaan Opini Audit Going Concern. JOM Fekon, Vol.3 No.1, Februari 2016, pp. 1422-1435.

Rosiana, Gusti Ayu Made Ervina., Gede Juliarsa., dan Maria M. Ratna Sari. 2013. Pengaruh Pengungkapan CSR Terhadap Nilai Perusahaan Dengan Profitabilitas Sebagai Variabel Pemoderasi. E-Jurnal Akuntansi Universitas Udayana. Vol. 5 No. 3, pp. 723-738.

Sandi, Lukyanto Dwi., Adi Prasetyo., dan Eris Tri Kurniawati. 2014. Pengaruh Debt Default, Firm Size, Dan Prior Opinion Terhadap Penerimaan Opini Going Concern. Jurnal Reviu Akuntansi dan Keuangan. Vol. 4 No. 1, April 2014, pp. 571-578.

Sari, Dewi Ratna, dan Sri Wahyuni. 2014. Pengaruh Kualitas Audit, Pertumbuhan Perusahaan, Likuiditas dan Solvabilitas Terhadap Opini Audit Going Concern. KOMPARTEMEN. Vol. 12 No.1, Maret 2014. 
Setyarno, Eko Budi., dan Indira Januarti. 2006. Pengaruh Kualitas Audit, Kondisi Keuangan Perusahaan, Opini Audit Tahun Sebelumnya, Pertumbuhan Perusahaan Terhadap Opini Audit Going Concern. Simposium Nasional Akuntansi 9 Padang 1.

Sidqi, Dharma Lisan., dan Sutapa. 2014. Pengaruh Financial Distress Dan Audit Client Tenure Terhadap Penerimaan Opini Audit Going Concern. Jurnal Akuntansi Indonesia, Vol. 3 No. 1, Januari 2014, pp. 1 - 12.

Siregar, Baldric., dan Abdul Rahman. 2012. Kecenderungan Penerimaan Opini Audit Going Concern. JRAK. Vol. 8, No. 2, Agustus 2012.

Solikhah, Badingatus., Abdul Rohman., dan Wahyu Meiranto. 2010. Implikasi Intellectual Capital Terhadap Financial Performance, Growth Dan Market Value; Studi Empiris Dengan Pendekatan Simplistic Specification.

Sugiyono. 2010. Metode Penelitian: Alfabeta

. 2013. Metode Penelitian: Alfabeta . 2014. Metode Penelitian Kombinasi: Alfabeta 2016. Statistika Untuk Penelitian: Alfabeta 2017. Statistika Untuk Penelitian: Alfabeta

Suharsono, Riyanto Setiawan. 2018. Pengaruh Kualitas Audit, Debt Default dan Pertumbuhan Perusahaan Terhadap Penerimaan Opini Audit Going Concern. Jurnal Ilmiah Ilmu Akuntansi, Keuangan dan Pajak. Vol. 2, No. 1, Januari 2018.

Suhendah, Rousilita. 2010. Pengaruh Intellectual Capital Terhadap Profitabilitas, Produktivitas, Dan Penilaian Pasar.

Susanto, Yulius Kurnia. 2009. Faktor-Faktor Yang Mempengaruhi Penerimaan Opini Audit Going Concern. Jurnal bisnis Dan akuntansi. Vol. 11 No. 3, Desember 2009, pp. 155-173.

Umar, Husein. 2014. Metode Penelitian untuk skripsi dan tesis bisnis.

Verdiana, Komang Anggita., dan I Made Karya Utama. 2013. Pengaruh Reputasi Auditor, Disclosure, Audit Client Tenure Pada Kemungkinan Pengungkapan Opini Audit Going Concern. E-Jurnal Akuntansi Universitas Udayana. Vol. 5 No. 3, 2013, pp. 530-543.

Werastuti, Desak Nyoman Sri. 2013. Pengaruh Auditor Client Tenure, Debt Default, Reputasi Auditor, Ukuran Klien dan Kondisi Keuangan Terhadap Kualitas Audit Melalui Opini Audit Going Concern. Jurnal Riset Akuntansi. Vol. 2 No.1, April 2013. 
Wulandari, Soliyah. 2014. Analisis Faktor-Faktor Yang Mempengaruhi Auditor Dalam Memberikan Opini Audit Going Concern. E-Jurnal Akuntansi Universitas Udayana. Vol. 6 No. 3, 2014, 531-558

Yuliyani, Ni Made Ade., dan Ni Made Adi Erawati. 2017. Pengaruh Financial Distress, Profitabilitas, Leverage dan Likuiditaspada Opini Audit Going Concern. E-Jurnal Akuntansi Universitas Udayana. Vol.19 No. 2, Mei 2017, pp. 1490-1520.

Sumber dari internet :

Djumena, Erlangga. Ekonomi Lesu, 125 perusahaan batu bara bangkrut, 5000 orang kena PHK. Diakses pada tanggal 15 Juli 2018 dari http://ekonomi.kompas.com/read/2015/08/12/060100026/Ekonomi.Lesu/125.Peru sahaan.Batu.Bara.Bangkrut.5.000.Orang.Kena.PHK

Rantelino, Heriyanto. Mengintip Prospek Industri Pertambangan Indonesia. Diakses pada 15 Juli 2018 dari http://www.kompasiana.com/ heriyanto_rantelino/mengintip-prospek industri-pertambangan-indonesia_ 552a462ef17e614670d6246d

Rambeth, Daniel. Tahun 2015 sebagai tahun terburuh bagi sektor pertambangan. diakses pada tanggal 15 Juli 2018 dari http://www.pwc.com/id/en/mediacentre/pwc-in-news/2016/indonesia/pwc-tahun-2015-sebagai-tahun terburuk-bagisektor-pertambangan-html 